\title{
Portulaca oleracea Linn seed extract ameliorates hydrogen peroxide-induced cell death in human liver cells by inhibiting reactive oxygen species generation and oxidative stress
}

\author{
Ebtesam S Al-Sheddi ${ }^{1}$, Nida N Farshori $^{1}$, Mai M Al-Oqail ${ }^{1}$, Shaza M Al- \\ Massarani ${ }^{1}$, Abdullah M Al Salem ${ }^{2,3}$, Javed Musarrat ${ }^{2,3}$, Abdulaziz A Al- \\ Khedhairy ${ }^{2}$ and Maqsood A Siddiqui ${ }^{2,3 *}$ \\ ${ }^{1}$ Department of Pharmacognosy, College of Pharmacy, ${ }^{2}$ Zoology Department, ${ }^{3}$ Al-Jeraisy Chair for DNA Research, Zoology \\ Department, College of Science, King Saud University, PO Box 2455, Riyadh 11451, Saudi Arabia
}

*For correspondence: Email: maqsoodahmads@gmail.com; Tel: 00966-542967835

Received: 31 March 2016

Revised accepted: 2 July 2016

\begin{abstract}
Purpose: To investigate the protective effects of Portulaca oleracea seed extract (POA) against cytotoxicity, oxidative stress and reactive oxygen species (ROS) generation induced by hydrogen peroxide $\left(\mathrm{H}_{2} \mathrm{O}_{2}\right.$ ) in human liver cells (HepG2).

Methods: The extract (POA) was obtained by ethanol extraction of $P$. oleracea seeds. Cytotoxicity in HepG2 cells was assessed by 3-(4,5-dimethylthiazol-2-yl)-2,5-diphenyl tetrazolium bromide (MTT) assay, neutral red uptake (NRU) assay and morphological changes. The cells were pre-exposed to noncytotoxic concentrations (5 - $25 \mu \mathrm{g} / \mathrm{mL}$ ) of POA for $24 \mathrm{~h}$, and then cytotoxic $(0.25 \mathrm{mM}$ ) concentration of $\mathrm{H}_{2} \mathrm{O}_{2}$. After $24 \mathrm{~h}$ of exposure, MTT and NRU assays were used to evaluate cell viability, while morphological changes were assessed using phase contrast inverted microscopy. The effect of $P O A$ on reduced glutathione (GSH) level, lipid peroxidation (LPO), and ROS generation induced by $\mathrm{H}_{2} \mathrm{O}_{2}$ was also studied.

Results: The results showed that pre-exposure to POA $(25 \mu \mathrm{g} / \mathrm{mL})$ significantly $(p<0.01)$ attenuated the loss of cell viability by up to $38 \%$ against $\mathrm{H}_{2} \mathrm{O}_{2}$-induced oxidative stress and ROS generation. In addition, POA $(25 \mu \mathrm{g} / \mathrm{mL})$ significantly $(p<0.01)$ increased GSH level $(31 \%)$, but decreased the levels of $L P O(37 \%)$ and ROS generation ( $49 \%)$.

Conclusion: This study demonstrates that POA has the capacity to protect HepG2 cells against $\mathrm{H}_{2} \mathrm{O}_{2-}$ induced cell death by inhibiting oxidative stress and ROS generation.
\end{abstract}

Keywords: Portulaca oleracea, HepG2 cells, Cytotoxicity, Oxidative stress, Reactive oxygen species

Tropical Journal of Pharmaceutical Research is indexed by Science Citation Index (SciSearch), Scopus, International Pharmaceutical Abstract, Chemical Abstracts, Embase, Index Copernicus, EBSCO, African Index Medicus, JournalSeek, Journal Citation Reports/Science Edition, Directory of Open Access Journals (DOAJ), African Journal Online, Bioline International, Open-J-Gate and Pharmacy Abstracts

\section{INTRODUCTION}

Oxidative stress is caused by an imbalance in the amount of reactive oxygen species (ROS) and antioxidant defense systems in biological system [1]. It is one of the most important factors inducing cell apoptosis [2]. Oxidative stress can increase the vulnerability to lipid peroxidation, DNA damage, enzymatic inactivation, and cell death [3]. It has been reported that overproduction of ROS plays a major role in hepatocarcinoma [4], and cellular damage [5]. $\mathrm{H}_{2} \mathrm{O}_{2}$ has been reported to induce cytotoxicity and apoptotic cell death in a variety of cell 
systems [6], including human liver cells (HepG2) [7].

$\mathrm{H}_{2} \mathrm{O}_{2}$-induced ROS generation and oxidative stress have been reported previously [8]. Thus, used $\mathrm{H}_{2} \mathrm{O}_{2}$ to induce cytotoxicity, oxidative stress, and ROS generation in HepG2 cells. Portulaca oleracea (Family: Portulacaceae), is an annual green herbaceous medicinal plant widespread in temperate and tropical regions worldwide [9]. It has been used as a vegetable for human consumption and is recognized for its numerous benefits [10]. The pharmacological and preventive properties of $P$. oleracea, such as anti-inflammatory, antioxidative, anti-bacterial, skeletal muscle relaxant, wound-healing, and in vitro anti-tumor have been reported [11].

It was recently demonstrated that the seed extract and oil of $P$. oleracea induced cytotoxicity in human liver cancer cells [11]. However, the mechanism(s) of the protective effects of $P$. oleracea against $\mathrm{H}_{2} \mathrm{O}_{2}$, induced oxidative stress and ROS generation in HepG2 have not been evaluated.

Therefore, this study was aimed to investigate the protective effects of $P$. oleracea against $\mathrm{H}_{2} \mathrm{O}_{2}$ induced cytotoxicity and oxidative stress in HepG2 cells. HepG2 cells have been shown to be a good model system for assessing the toxicity or detoxification of various compounds against oxidative stress inducers [12].

\section{EXPERIMENTAL}

\section{Materials}

DMEM culture medium, antibiotics-antimycotic solution, fetal bovine serum (FBS), and trypsin were purchased from Invitrogen (Carlsbad, CA, USA). Consumables and culture products used in the study were obtained from Nunc (Roskilde, Denmark). $\mathrm{H}_{2} \mathrm{O}_{2}$ and all other specified chemicals and reagents were purchased from Sigma (St. Louis, MO, USA).

\section{Plant material and extraction}

The seeds of $P$. oleracea used in this study were obtained from a local market in Riyadh, Saudi Arabia. The seeds were screened manually. For the preparation of alcoholic extract, the seeds were macerated in ethanol and then filtered. The procedure was repeated five times. The solvent was then evaporated using a rotary evaporator and the residue obtained was named the alcoholic extract (POA).

\section{Cell culture}

HepG2 cells were cultured in DMEM, supplemented with $10 \%$ fetal bovine serum, 0.2 $\%$ sodium bicarbonate and antibiotic/antimycotic solution $(100 \times, 1 \mathrm{~mL} / 100 \mathrm{~mL}$ of medium). Cells were grown in $5 \% \mathrm{CO}_{2}$ at $37{ }^{\circ} \mathrm{C}$ in high humidity atmosphere. Before the experiments, cell viability was assessed as described by Siddiqui et al [20]. HepG2 cells showing more than $98 \%$ cell viability and at passage numbers $20-22$ were used in this study.

\section{Drug solutions}

The POA was not completely soluble in the culture medium; therefore the stock solutions of the extract were prepared in dimethyl sulphoxide (DMSO) and diluted in culture medium to reach the desired concentrations. $\mathrm{H}_{2} \mathrm{O}_{2}$ was freshly diluted in culture medium before addition to the cells.

\section{Cytotoxicity by MTT assay}

The percentage cell viability was assessed using the 3-(4,5-dimethylthiazol-2-yl)-2,5-diphenyl tetrazolium bromide (MTT) assay as described previously [13]. Briefly, HepG2 cells $\left(1 \times 10^{4}\right)$ were allowed to adhere for $24 \mathrm{~h}$ in a $\mathrm{CO}_{2}$ incubator at $37^{\circ} \mathrm{C}$ in 96-well culture plates. After $24 \mathrm{~h}$ exposure of HepG2 cells to increasing concentrations (5 - 500 $\mu \mathrm{g} / \mathrm{mL})$ of POA for $24 \mathrm{~h}$, MTT $(5 \mathrm{mg} / \mathrm{mL}$ of stock in PBS) was added (10 $\mu \mathrm{L} /$ well in $100 \mu \mathrm{L}$ of cell suspension), and the plates were incubated for $4 \mathrm{~h}$. The supernatant was discarded and $200 \mu \mathrm{L}$ of DMSO was added to each well and mixed gently. The developed color was read at $550 \mathrm{~nm}$ in a multiwell microplate reader (Thermo Scientific, Waltham, MA, USA). Untreated sets were also run under identical conditions as controls.

\section{Neutral red uptake (NRU) assay}

The NRU assay was carried out as described by Siddiqui et al [13]. Briefly, after $24 \mathrm{~h}$ exposure of HepG2 cells to increasing concentrations (5 $500 \mu \mathrm{g} / \mathrm{mL}$ ) of POA for $24 \mathrm{~h}$, the medium was aspirated and the cells were washed twice with PBS and incubated for $3 \mathrm{~h}$ in medium supplemented with neutral red $(50 \mu \mathrm{g} / \mathrm{mL})$. The medium was rapidly removed with a solution containing $0.5 \%$ formaldehyde and $1 \%$ calcium chloride. The cells were subjected to further incubation for $20 \mathrm{~min}$ at $37{ }^{\circ} \mathrm{C}$ in a mixture of acetic acid (1\%) and ethanol (50\%) to extract the dye. The plates were read at $540 \mathrm{~nm}$ in a multi-well microplate reader (Thermo Scientific). 
The values were compared with the control sets run under identical conditions.

\section{Assessment of morphological alterations}

Morphological changes in HepG2 cells exposed to increasing concentrations of POA (5 - 500 $\mu \mathrm{g} / \mathrm{mL}$ ) for $24 \mathrm{~h}$ were observed using a phase contrast inverted microscope (Olympus, Tokyo, Japan) equipped with automatic image analysis software. Further, to observe the protective effects of POA on cellular morphology, HepG2 cells were treated with non-cytotoxic concentrations $(5,10$ and $25 \mu \mathrm{g} / \mathrm{mL}$ ) of POA for $24 \mathrm{~h}$ before treatment with $\mathrm{H}_{2} \mathrm{O}_{2}(0.25 \mathrm{mM})$ for 24 $\mathrm{h}$.

\section{Determination of glutathione (GSH) level}

The intracellular level of reduced GSH was estimated as described by Chandra et al [14] with some modifications. Briefly, HepG2 cells exposed to POA and $\mathrm{H}_{2} \mathrm{O}_{2}$ were collected by centrifugation and the cellular proteins were precipitated by incubating $1 \mathrm{~mL}$ sonicated cell suspension with $10 \%$ trichloroacetic acid $(1 \mathrm{~mL})$ on ice for $1 \mathrm{~h}$ followed by centrifugation at 3000 $\mathrm{rpm}$ for $10 \mathrm{~min}$. The supernatant was then added to $2 \mathrm{~mL}$ buffer $(0.4 \mathrm{M}$ Tris and $0.02 \mathrm{M}$ EDTA; $\mathrm{pH}$ 8.9) and $0.01 \mathrm{M}$ of 5,5'-dithionitrobenzoic acid to reach a final volume of $3 \mathrm{~mL}$. The tubes were incubated for $10 \mathrm{~min}$ at $37^{\circ} \mathrm{C}$ in a shaking water bath. The absorbance of the yellow color developed was read at $412 \mathrm{~nm}$.

\section{Evaluation of lipid peroxidation (LPO)}

LPO was evaluated using thiobarbituric acidreactive substances protocol [15]. Briefly, after exposing HepG2 cells to POA and $\mathrm{H}_{2} \mathrm{O}_{2}$, $\mathrm{HepG} 2$ cells were collected by centrifugation, sonicated in ice-cold potassium chloride (1.15\%), and centrifuged again for $10 \mathrm{~min}$ at $3000 \times \mathrm{g}$. The resulting supernatant $(1 \mathrm{~mL})$ was collected and 2 $\mathrm{mL}$ of thiobarbituric acid reagent (15\% trichloroacetic acid, $0.7 \%$ thiobarbituric acid and

(A)

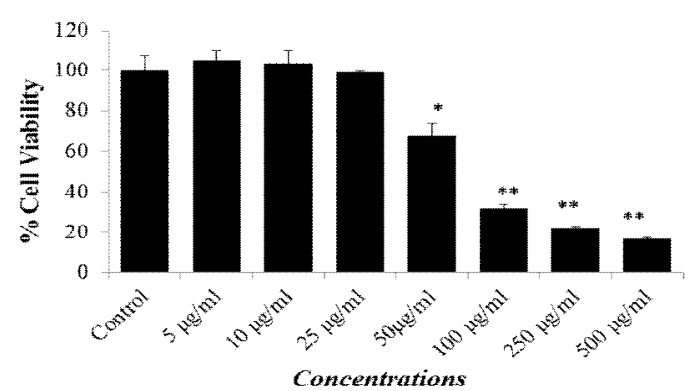

$0.25 \mathrm{NHCl}$ ) was added. The solution was heated at $100{ }^{\circ} \mathrm{C}$ for $15 \mathrm{~min}$ in a boiling bath. The sample was then placed at a cold temperature and centrifuged at $1000 \times \mathrm{g}$ for $10 \mathrm{~min}$. Absorbance of the supernatant was measured at $535 \mathrm{~nm}$.

\section{Determination of reactive oxygen species (ROS) generation}

ROS generation was assessed using 2,7dichlorodihydrofluoresceindiacetate (DCFH-DA; Sigma) dye as a fluorescence agent described previously [16]. Following exposure to POA and $\mathrm{H}_{2} \mathrm{O}_{2}$ for $24 \mathrm{~h}$, the cells were washed with PBS and incubated for $30 \mathrm{~min}$ in DCFH-DA $(20 \mu \mathrm{M})$ containing incomplete culture medium in the dark at $37{ }^{\circ} \mathrm{C}$. Next, the cells were analyzed for intracellular fluorescence using a fluorescence microscope.

\section{Statistical analysis}

The results were expressed as the mean \pm SEM of at least three independent experiments (conducted in triplicate). Statistical analysis was performed using one-way analysis of variance using Dunnett's post hoc test employed to compare the values between control and treated groups. Differences were considered statistically significant at $p<0.05$.

\section{RESULTS}

\section{Cytotoxicity of POA}

The results showed that POA concentrations of 5,10 and $25 \mu \mathrm{g} / \mathrm{mL}$ had no significant effects on the viability of HepG2 cells (Figure 1 and Figure 2). Therefore, the concentrations 5,10 and 25 $\mu \mathrm{g} / \mathrm{mL}$ of POA were used to study the protective effects against $\mathrm{H}_{2} \mathrm{O}_{2}$-induced toxicity in HepG2 cells. Further, based on the $\mathrm{LD}_{50}$ value, $0.25 \mathrm{mM}$ of $\mathrm{H}_{2} \mathrm{O}_{2}$ was used to induce toxicity in further experiments.

(B)

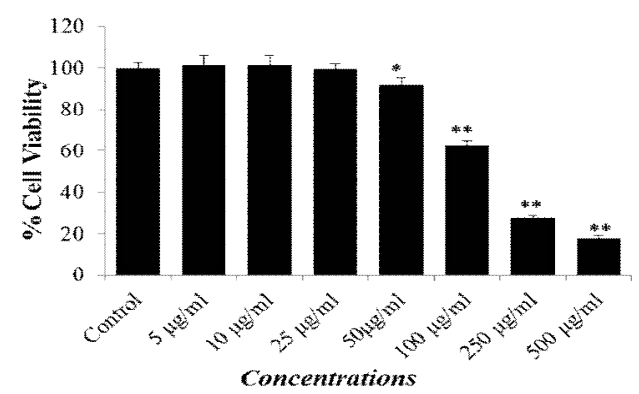

Figure 1: Cell viability based on (A) MTT and (B) NRU assays in HepG2 cells following exposure to various concentrations of Portulaca oleracea extract (POA) for $24 \mathrm{~h}$. Values are mean $\pm \operatorname{SEM}(n=3) ;{ }^{*} p<0.05$, ${ }^{* *} p<0.01$ vs. control 


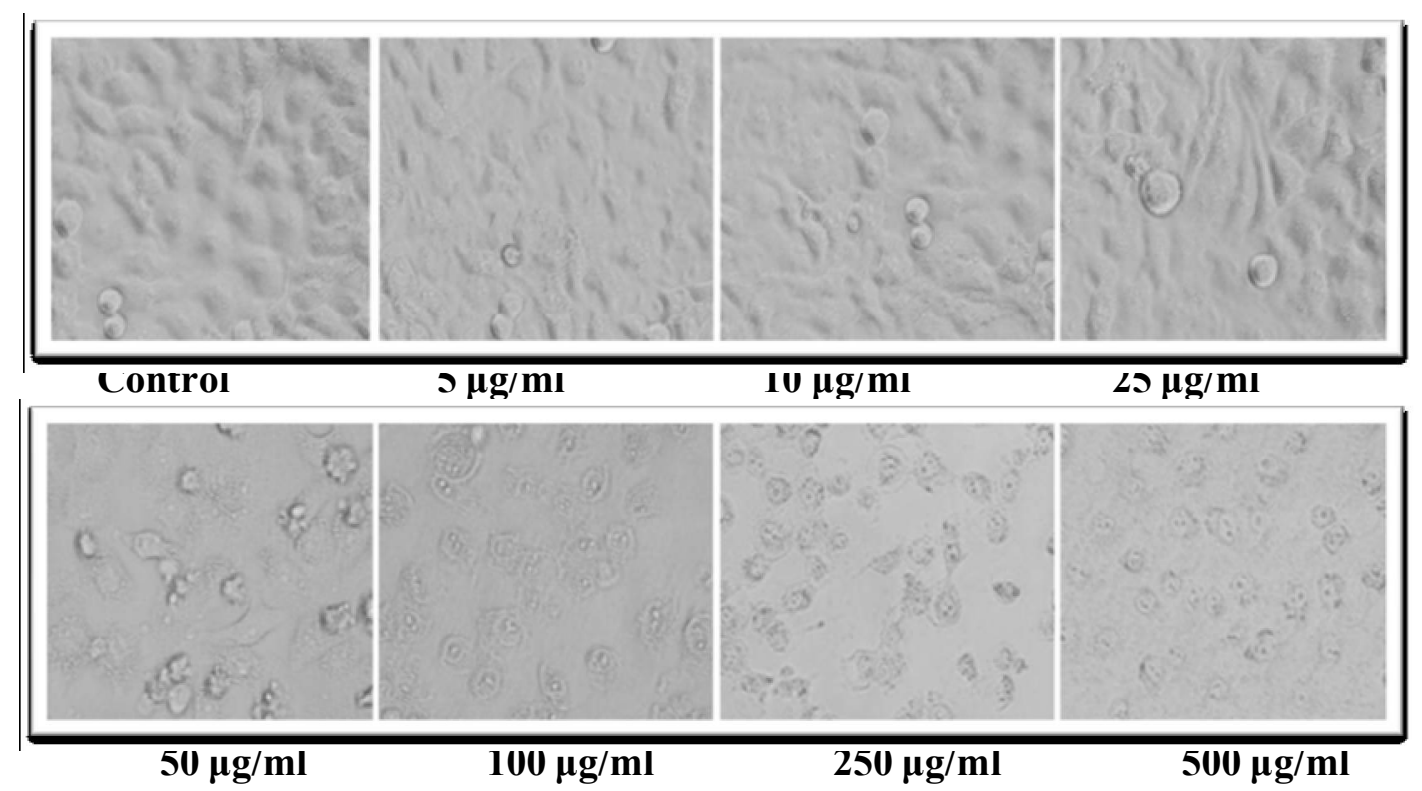

Figure 2: Morphological alterations in HepG2 cells following the exposure to various concentrations of Portulaca oleracea extract (POA) for $24 \mathrm{~h}$. Images were taken using an inverted phase contrast microscope (OLYMPUS CKX 41) at 20× magnification

\section{Protective effect of POA against $\mathrm{H}_{2} \mathrm{O}_{2}$ induced cell death}

The protective potential of POA in HepG2 cells observed in the MTT and NRU assays are presented in Figure 3. A significant $(p<0.01)$ reduction in the percentage of cell viability was observed in HepG2 cells following exposure to $\mathrm{H}_{2} \mathrm{O}_{2}(0.25 \mathrm{mM})$ for $24 \mathrm{~h}$ by MTT assay (Figure $3 \mathrm{~A}$ ) and NRU assay (Figure 3B). HepG2 cells pre-treated with $\mathrm{POA}$ at 5,10 and $25 \mu \mathrm{g} / \mathrm{mL}$ for $24 \mathrm{~h}$ significantly attenuated the $\mathrm{H}_{2} \mathrm{O}_{2}$-induced loss of cell viability in a concentration-dependent manner. Increases of 11,26 , and $38 \%$ in the cell viability of HepG2 cells were recorded at 5,10 , and $25 \mu \mathrm{g} / \mathrm{mL}$ of POA, respectively (Figure $3 \mathrm{~A}$ ). A similar concentration-dependent increase in cell viability was observed in the NRU assay in POA pre-exposed HepG2 cells. Increases of 15,
28 , and $40 \%$ in cell viability of HepG2 cells were recorded at 5,10 , and $25 \mu \mathrm{g} / \mathrm{mL}$ of $P O A$, respectively (Figure 3B).

\section{Morphological changes}

Alterations in the morphology of HepG2 cells following exposure to $\mathrm{POA}$ and $\mathrm{H} 2 \mathrm{O} 2$ are shown in Figure 4(A - E). Exposure to $0.25 \mathrm{mM}$ of $\mathrm{H}_{2} \mathrm{O}_{2}$ reduced the normal morphology and cell adhesion capacity of HepG2 cells compared to controls. Most cells exposed to $\mathrm{H}_{2} \mathrm{O}_{2}$ lost their typical morphology and appeared smaller in size (Figure 4B). Exposure of HepG2 cells to increasing concentrations of POA for $24 \mathrm{~h}$ prior to $\mathrm{H}_{2} \mathrm{O}_{2}$ exposure significantly restored their original morphology in a concentrationdependent manner (Figure 4C - E).

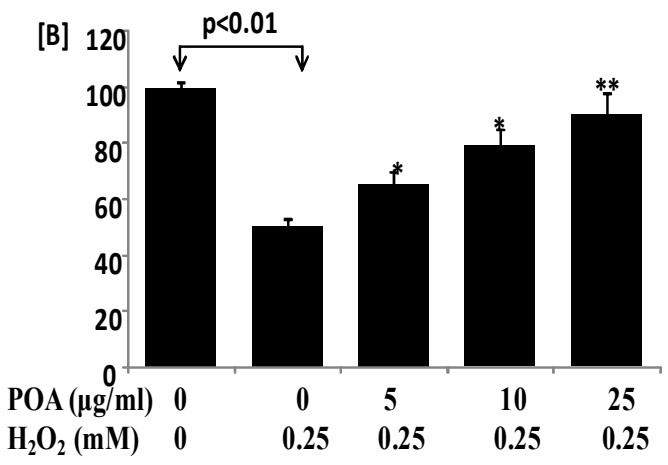

Figure 3: Cell viability by (A) MTT and (B) NRU assays in HepG2 cells. HepG2 cells were exposed to $5-25$ $\mu \mathrm{g} / \mathrm{mL}$ of POA for $24 \mathrm{~h}$. Next, the cells were exposed to $0.25 \mathrm{mM}$ of $\mathrm{H}_{2} \mathrm{O}_{2}$ for $24 \mathrm{~h}$. Values are mean $\pm \mathrm{SEM}(\mathrm{n}=$ 3 ); ${ }^{*} p<0.05,{ }^{* *} p<0.01$ versus $\mathrm{H}_{2} \mathrm{O}_{2}$ exposure 


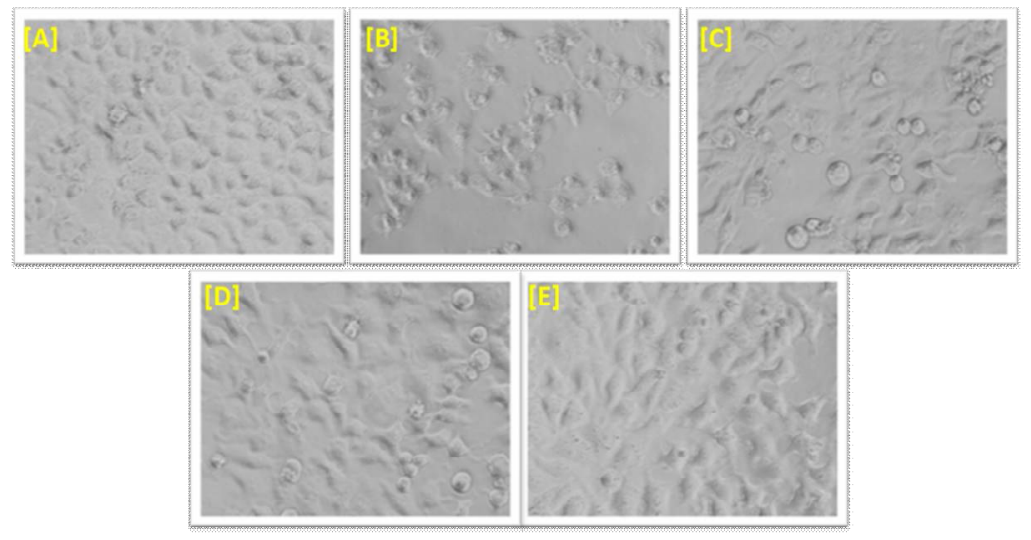

Figure 4: Morphological changes of HepG2. Cells were pre-exposed to POA for $24 \mathrm{~h}$ and then $\mathrm{H}_{2} \mathrm{O}_{2}$ for $24 \mathrm{~h}$. Image were acquired using a phase contrast inverted microscope at 20× magnification. [A] Control, [B] $\mathrm{H}_{2} \mathrm{O}_{2}$ (0.25 mM), [C] POA $(5 \mu \mathrm{g} / \mathrm{mL})+\mathrm{H}_{2} \mathrm{O}_{2}(0.25 \mathrm{mM})$, [D] POA $(10 \mu \mathrm{g} / \mathrm{mL})+\mathrm{H}_{2} \mathrm{O}_{2}(0.25 \mathrm{mM})$, and [E] POA (25 $\mu \mathrm{g} / \mathrm{mL})+\mathrm{H}_{2} \mathrm{O}_{2}(0.25 \mathrm{mM})$
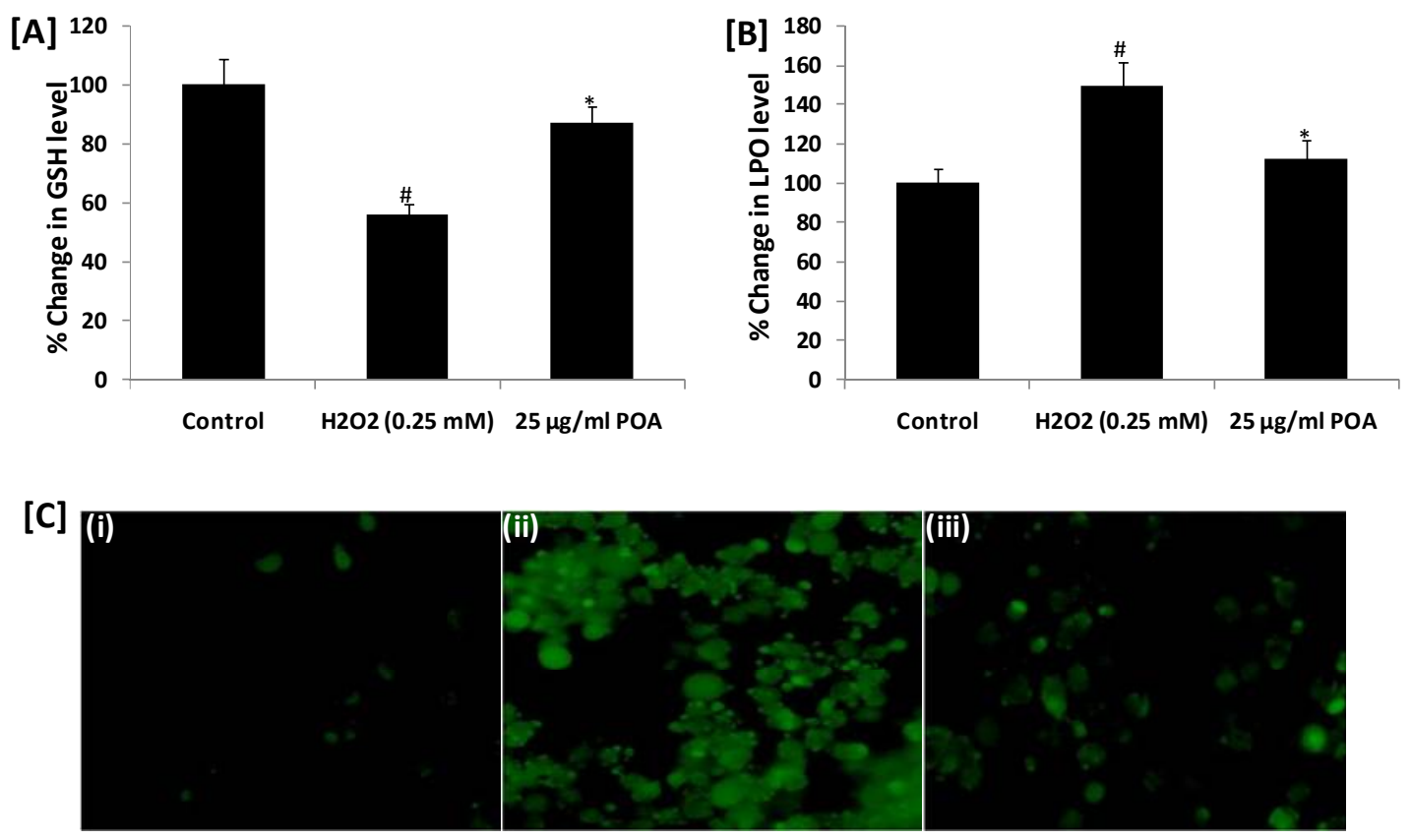

Figure 5: Protective potential of POA on [A] Glutathione (GSH) and [B] Lipid peroxidation (LPO) levels in HepG2 following the exposure to POA $(25 \mu \mathrm{g} / \mathrm{mL})$ for $24 \mathrm{~h}$ then $\mathrm{H}_{2} \mathrm{O}_{2}$ for $24 \mathrm{~h}$. All values represent the mean $\pm \mathrm{SE}$. $\# p<0.01$ vs. control, * $p<0.01$ versus $\mathrm{H}_{2} \mathrm{O}_{2}$ exposure. [C] $\mathrm{H}_{2} \mathrm{O}_{2}$-induced ROS generation and ameliorative effect of pre-treatment of POA in HepG2 cells. ROS generation was evaluated using dichlorofluorescin diacetate (DCFHDA) dye. (i): Untreated control, (ii): Cells exposed to $\mathrm{H}_{2} \mathrm{O}_{2}(0.25 \mathrm{mM})$ for $24 \mathrm{~h}$, (iii): Cells exposed to $25 \mu \mathrm{g} / \mathrm{mL}$ of POA for $24 \mathrm{~h}$ and then $\mathrm{H}_{2} \mathrm{O}_{2}(0.25 \mathrm{mM})$

\section{GSH level}

The protective potential of POA on $\mathrm{H}_{2} \mathrm{O}_{2}$-induced depletion in GSH level is summarized in Figure $5 \mathrm{~A}$. As shown in the figure, exposure of HepG2 cells to $0.25 \mathrm{mM}$ of $\mathrm{H}_{2} \mathrm{O}_{2}$ significantly reduced the GSH level by $44 \%(p<0.01)$ compared to the control. The results also showed that 25 $\mu \mathrm{g} / \mathrm{mL}$ POA significantly prevented $(p<0.01)$ the decrease in GSH levels caused by $\mathrm{H}_{2} \mathrm{O}_{2}$ in HepG2 cells (Figure 5A).

\section{LPO levels}

The protective potential of various concentrations of $\mathrm{POA}$ on $\mathrm{H}_{2} \mathrm{O}_{2}$-induced lipid peroxidation in HepG2 cells is summarized in Figure 5B. As shown in the figure, exposure to $\mathrm{H}_{2} \mathrm{O}_{2}$ resulted in a significant increase of $49 \%(p<0.01)$ in LPO 
compared to in control cells. HepG2 cells pretreated with $25 \mu \mathrm{g} / \mathrm{mL}$ POA for $24 \mathrm{~h}$ prior to $\mathrm{H}_{2} \mathrm{O}_{2}$ treatment showed significantly $(p<0.01)$ reduced LPO levels (Figure 5B).

\section{ROS generation}

The results of ROS generation in HepG2 cells exposed to $\mathrm{H}_{2} \mathrm{O}_{2}$ and various concentrations of POA are presented in Figure 5C. Exposure of HepG2 cells to $0.25 \mathrm{mM} \mathrm{H}_{2} \mathrm{O}_{2}$ for $24 \mathrm{~h}$ resulted in ROS production. Pre-treatment of cells with 25 $\mu \mathrm{g} / \mathrm{Ml} \mathrm{POA}$ concentration significantly reduced the ROS generation induced by $\mathrm{H}_{2} \mathrm{O}_{2}$ in $\mathrm{HepG} 2$ cells (Figure 5C).

\section{DISCUSSION}

Oxidative stress is associated with a variety of human diseases [17]. There is increasing interest in naturally derived bioactive compounds with potential cytoprotective effects against oxidative stress-induced cell death [18]. Because oxidative stress appears to be involved in many diseases, the administration of antioxidants may be useful for preventing and treating these diseases [19]. Based on previous study, which revealed that $\mathrm{H}_{2} \mathrm{O}_{2}$ induces cytotoxicity in HepG2 cells in a concentration dependent manner [20], $0.25 \mathrm{mM}$ $\mathrm{H}_{2} \mathrm{O}_{2}$ was used to induce cytotoxicity, oxidative stress and ROS generation in HepG2 cells.

The pharmacological activities of $P$. oleracea such as anti-inflammatory, antioxidative, antibacterial, skeletal muscle relaxant, woundhealing, and in vitro anti-tumor have been documented [11]. However, the protective effects of $P$. oleracea on oxidative stress and ROS generation in HepG2 cells induced by $\mathrm{H}_{2} \mathrm{O}_{2}$ had not been examined. The present study was carried out to assess the protective effects of POA in HepG2 cells. The data indicate that the pre-treatment of HepG2 cells with POA $(5-25$ $\mu \mathrm{g} / \mathrm{mL}$ ) had protective effects on the viability of HepG2 cells against $\mathrm{H}_{2} \mathrm{O}_{2}$-induced cytotoxicity. The results agree with previous findings, where the extracts of natural products showed cytoprotective potential against $\mathrm{H}_{2} \mathrm{O}_{2}$ [6]. It has also been reported that natural products protect liver cells against $\mathrm{H}_{2} \mathrm{O}_{2}$ [20] and other toxicants [21]. The results also showed that $\mathrm{H}_{2} \mathrm{O}_{2}$ reduced the GSH level in HepG2 cells compared to in untreated controls. Pre-treatment of HepG2 cells with $P O A$ at $25 \mu \mathrm{g} / \mathrm{mL}$ significantly restored the decrease in the GSH level caused by $\mathrm{H}_{2} \mathrm{O}_{2}$. It is also known that glutathione peroxidase catalyzes GSH oxidation to GSSG at the expense of $\mathrm{H}_{2} \mathrm{O}_{2}$ and that glutathione reductase recycles oxidized
GSH back to reduced GSH [22]. Thus, it can be hypothesized that POA pre-treatment of HepG2 cells reduced the intracellular damaging peroxide and recovered $\mathrm{GSH}$ concentration. The restoration of GSH clearly indicates that POA plays an important role in the cell defense system against $\mathrm{H}_{2} \mathrm{O}_{2}$. Lipid peroxidation is known to be involved in oxidative stress and cell death [23]. In the present study, $\mathrm{H}_{2} \mathrm{O}_{2}$ increased lipid peroxidation in HepG2 cells. The results support those of previous studies [24], where an increase in LPO level due to $\mathrm{H}_{2} \mathrm{O}_{2}$ was observed. This increase in lipid peroxidation in HepG2 cells by $\mathrm{H}_{2} \mathrm{O}_{2}$ may be related to the enhancement of hepatic MDA from the peroxidation of polyunsaturated fatty acids [20]. The results also showed that exposure to HepG2 cells to 25 $\mu \mathrm{g} / \mathrm{mL}$ POA significantly decreased lipid peroxidation levels. An increase in ROS generation indicates that $\mathrm{H}_{2} \mathrm{O}_{2}$ can cause oxidative stress in HepG2 cells. The results showed that pre-treatment with POA significantly reduced intracellular ROS generation induced by $\mathrm{H}_{2} \mathrm{O}_{2}$. The findings of this study correlate with those of other reports showing that the administration of natural products suppressed the increases in intra-cellular ROS generation [6].

\section{CONCLUSION}

The findings of this study indicate that $P$. oleracea can protect human liver cells (HepG2) against $\mathrm{H}_{2} \mathrm{O}_{2}$-induced cytotoxicity by inhibiting ROS generation and oxidative stress. The results also provide insight into the biological activities of $P$. oleracea, suggesting that it is a good source of antioxidants.

\section{DECLARATIONS}

\section{Acknowledgement}

This project was financially supported by King Saud University, Vice Deanship of Research Chairs.

\section{Conflict of Interest}

No conflict of interest associated with this work.

\section{Contribution of Authors}

The authors declare that this work was done by the authors named in this article and all liabilities pertaining to claims relating to the content of this article will be borne by them. 


\section{REFERENCES}

1. Valavanidis A, Vlahogianni T, Dassenakis M, Scoullos $M$. Molecular biomarkers of oxidative stress in aquatic organisms in relation to toxic environmental pollutants. Ecotoxicol Environ Saf 2006; 64(2): 178-189.

2. Miyoshi N, Oubrahim H, Chock PB, Stadtman ER. Agedependent cell death and the role of ATP in hydrogen peroxide-induced apoptosis and necrosis. Proc Natl Acad Sci USA 2006; 103(6): 1727-1731.

3. Khalil WA, Marei WF, Khalid M. Protective effects of antioxidants on linoleic acid-treated bovine oocytes during maturation and subsequent embryo development. Theriogenol 2013; 80(2):161-168.

4. Zhang Y, Jiang L, Jiang L, Geng C, Li L, Shao J, Zhong L. Possible involvement of oxidative stress in potassium bromate-induced genotoxicity in human HepG2 cells. ChemBiol Inter 2011; 189(3): 186-191.

5. Lin PH, Lin CH, Huang CC, Chuang MC, Lin P. 2,3,7,8Tetrachlorodibenzo-p-dioxin (TCDD) induces oxidative stress, DNA strand breaks, and poly(ADP-ribose) polymerase-1 activation in human breast carcinoma cell lines. Toxicol Lett 2007; 172(3): 146-158.

6. Kanno SI, Shouji A, Asou K, Ishikawa M. Effects of naringin on hydrogen peroxide-induced cytotoxicity and apoptosis in P388 cells. J Pharma Sci 2003; 92(2): 166170.

7. Chen X, Zhong Z, Xu Z, Chen L, Wang Y. No protective effect of curcumin on hydrogen peroxide-induced cytotoxicity in HepG2 cells. Pharmacol Rep 2011; 63(3): 724-732.

8. Siddiqui MA, Kashyap MP, Kumar V, Tripathi VK, Khanna VK, Yadav S, Pant AB. Differential protection of pre-, coand post-treatment of curcumin against hydrogen peroxide in PC12 cells. Human Exper Toxicol 2011; 30(3): 192-198.

9. Yang Z, Liu C, Xiang L, Zheng Y. Phenolic alkaloids as a new class of antioxidants in Portulaca oleracea. Phytother Res 2009; 23(7): 1032-1035.

10. Bidhendi F, Ahmadi R, Siavashi M, Mahdavi E. The effects of Portulaca oleracea seed extract on RBC membrane stability in male and female rats. International conference on food, biological and medical sciences (FBMS-2014), January 28-29, Bangkok (Thailand).

11. Farshori NN, Al-Sheddi ES, Al-Oqail MM, Musarrat J, AlKhedhairy AA, Siddiqui MA. Cytotoxicity Assessments of Portulaca oleracea and Petroselinum sativum seed extracts on human hepatocellular carcinoma cells (HepG2). Asian Pac J Cancer Prev 2014; 15(16): 66336638.

12. Farshori NN, Al-Sheddi ES, Al-Oqail MM, Hassan WH, Al-Khedhairy AA, Musarrat J, Siddiqui MA. Hepatoprotective potential of Lavandula coronopifolia extracts against ethanol induced oxidative stressmediated cytotoxicity in HepG2 cells. Toxicol Ind Health 2015; 31(8): 727-737.

13. Siddiqui MA, Singh G, Kashyap MP, Khanna VK, Yadav $S$, Chandra D, Pant AB. Influence of cytotoxic doses of 4-hydroxynonenal on selected neurotransmitter receptors in PC-12 cells. Toxicolln Vitro 2008; 22(7): 1681-1688.

14. Chandra D, Ramana KV, Wang L, Christensen $B N$, Bhatnagar A, Srivastava SK. Inhibition of fiber cell globulization and hyperglycemia-induced lens opacification by amino peptidase inhibitor bestatin. Invest Ophthalmol Vis Sci2002; 43(7): 2285-2292.

15. Buege JA, Aust SD. Microsomal lipid peroxidation. Methods Enzymol1978; 52, 302-310.

16. Siddiqui MA, Ahmad J, Farshori NN, Saquib Q, Jahan $S$, Kashyap MP, Ahamed M, Musarrat J, Al-Khedhairy AA. Rotenone-induced oxidative stress and apoptosis in human liver HepG2 cells. Mol Cell Biochem 2013; 384(1-2): 59-69.

17. Valko $M$, Leibfritz $D$, Moncol J, Cronin MT, Mazur M, Telser J. Free radicals and antioxidants in normal physiological functions and human disease. Int $\mathrm{J}$ Biochem Cell Biol 2007; 39(1): 44-84.

18. Jaydeokar AV, Bandawane DD, Bibave KH, Patil TV. Hepatoprotective potential of Cassia auriculata roots on ethanol and anti-tubercular drug-induced hepatotoxicity in experimental models. Pharm Biol2014; 52(3): 344355.

19. Sekler A, Jiménez JM, Rojo L, Pastene E, Fuentes $P$, Slachevsky A, Maccioni RB. Cognitive impairment and Alzheimer's disease: Links with oxidative stress and cholesterol metabolism. Neuropsychiatr Dis Treat2008; 4(4): 715-722.

20. Al-Sheddi ES, Farshori NN, Al-Oqail MM, Musarrat J, AlKhedhairy $A A$, Siddiqui MA. Protective effect of Lepidium sativum seed extract against hydrogen peroxide-induced cytotoxicity and oxidative stress in human liver cells (HepG2). Pharm Biol 2016; 54(2): 314321.

21. Verma S, Bahorun T, Singh RK, Aruoma OI, Kumar A. Effect of Aegle marmelos leaf extract on N-methyl $\mathrm{N}$ nitrosourea-induced hepatocarcinogensis in Balb/c mice. Pharm Biol 2013; 51(10): 1272-1281.

22. Ursini F, Maiorino M, Brigelius- Floh, Aumann KD, Roveri $A$, Schomburg $D$, Flohé L. Diversity of glutathione peroxidases. Methods Enzymol1995; 252: 38-53.

23. Tribble DL, Tak YA, Dean $P$, Jones MD. The pathophysiological significance of lipid peroxidation in oxidative cell injury. Hepatol1987; 7(2):377-386.

24. Siddique $Y H$, Ara G, Afzal M. Estimation of lipid peroxidation induced by hydrogen peroxide in cultured human lymphocytes. Dose Response 2012; 10(1): 1-10. 